Wits Library: a centenary history

Musiker, Reuben \& Musiker, Naomi

Johannesburg: Scarecrow Books

1998

ISBN 0-620-22754-0

$181 \mathrm{p}$.

R95.00

The University of the Witwatersrand Library is one of Africa's major libraries. In Southern Africa itself, it is a leading tertiary education library. The history of the library spans the entire century, and its story has now been told for the first time.

In essence the history of a library is the story of people decision makers, librarians, donors, supporters and users. Reuben and Naomi Musiker have sketched the dramatic tale of the aspirations and ideals, perseverance, dedication, conflict, successes and disappointments of the people of a large library. The value of this narrative lies in the direct contributions of key people, for example the foreword by former rector, Prof G.R. Bozzoli, and chapters by the late Isaac Isaacson (Deputy University Librarian), Reuben Musiker (former University Librarian), Heather Edwards (current 
University Librarian) and Clare Walker (former Library Science lecturer).

In the seventy years since the appointment of Percy Freer there have been only five University Librarians and all of them have played important roles on the campus and in the library profession. For a long period university committees, such as the Board of Control of the Library (comprised of Council and Senate members) and the Senate Library Committee had a say in the affairs of the library administration. This measure of control had its advantages, but apparently also led to conflict. (One such conflict situation led to the resignation of the second University Librarian.)

The history of the Wits Library will serve as a valuable lesson for upcoming university libraries and new library managers. The problem created for library management by the decentralised structure, an inheritance of the University's early years, and the manner in which it was dealt with, offers interesting and informative reading matter.

The way the Library managed to canvass supporters from the ranks of the alumni, the campus population and the private sector, is a success story. It channelled a sustained source of monetary and book donations as well as archive material to the Library and established a strong moral support corps. This resulted in funding for the erection of library buildings and the purchase of a number of valuable Africana and specialised subject collections. The six unique Africana collections are described. Apart form these the library also owns valuable subject collections on Hebraica and Judaica, Law, Portugese studies and Music.

The library also experienced dramatic setbacks like the destructive fire on Christmas Eve 1931, when 35000 books, including half of the Gubbins Africana Collection, were destroyed. The loss of these valuable items can only be descibed as a national disaster. It inspired John Gubbins and other donors, in co-operation with the library staff, to build a bigger collection than the one that had been lost.
The broader academic community often takes the library for granted, but this book will shed more light on the various activities and input required for the running thereof. The Wits Library publication list (Appendix C) is an example of the different projects tackled by library staff. Text refers to, inter alia, prof Musiker's enormous contribution in the bibliographic field and to Heather Edwards' book University library building planning, the only authorative South African book on the subject.

The history of library science education and training at the University is documented by Musiker and Clare Walker.

Wits library is not merely an historical account. In chapter eight Heather Edwards, apart from giving a description of the rapid developments of the past decade, indicates clearly what contingencies have been planned for the demands that the future will bring. Meticulous attention is given, amongst others, to information technology and library co-operation.

The work is compiled with characteristic Musiker thoroughness and offers a complete overview without becoming drawn-out. It does not hesitate to expose shortcomings and negative aspects honestly, but also sufficiently accentuates the positive elements and strong points of a library on which its university can be proud and that has through the years made an indispensable contribution to the University of the Witwatersrand's academic excellence.

This publication is a milestone in the historiography of South African library science and everyone involved in university libraries should take note of its contents. For Wits alumni, supporters and staff, it is a beautiful souvenir of an important era in the history of their university.

\section{PIET AUCAMP}

Former Director, Library Services, Rand Afrikaans University, Johannesburg.

Translated by Tim Sandham. Editorial Board, South African journal of library and information science. 